\title{
Does Full Exposure of Clusters Have Any Negative Effects on Tempranillo (Vitis vinifera L.) Grape Quality in La Rioja, Spain? The Use of Severe Cluster-zone Leaf Removal after Berry Set
}

\author{
W. Zheng*, J. García, P. Balda, F. Martínez de Toda \\ Instituto de ciencias de la vid y del vino, ICVV (Universidad de La Rioja, CSIC, Gobierno de La Rioja), Finca La Grajera, \\ Autovía del Camino de Santiago LO-20 Salida 13, 26007 Logroño, La Rioja, Spain
}

Submitted for publication: March 2017

Accepted for publication: June 2017

Key words: Cluster full exposure, leaf removal, berry quality, warm climate

\begin{abstract}
A three-year experiment comprising severe leaf removal (LR) was carried out on Tempranillo grapes in Logroño, North-central Spain. For the LR treatment, six basal leaves, along with the basal lateral shoots, were removed two weeks after fruit set. Berry total soluble solids (TSS) were examined when the colour began to appear. Grapes from both the LR and control (C) vines were analysed at the same TSS level $\left(\approx 22^{\circ}\right.$ Brix). LR advanced the onset of anthocyanin synthesis slightly but significantly. Yield components were not affected by LR and no symptoms of sunburn were observed. Both treatments showed similar juice pH and titratable acidity, although tartaric acid increased with LR while malic acid decreased with it. In spite of failing to increase the final anthocyanin concentration of the grape juice, LR enhanced the colour and body of the wine. These results indicate that a relatively early LR could be a viable way to improve the quality of grapes and wine under the climatic conditions of the Rioja wine region.
\end{abstract}

\section{INTRODUCTION}

Due to climate change, grape sugar ripeness is no longer a big concern for the majority of the viticulturists around the world, especially in warm countries such as Spain. Instead, for the sake of wine balance, more attention is being paid to acidic aspects such as titratable acidity (TA), organic acid composition and $\mathrm{pH}$, as well as to the phenol ripeness (Martínez de Toda \& Balda, 2014). In this context, a number of cultural practices have been considered interesting to resynchronise polyphenolic ripening with sugar, and the core strategy is to delay the ripening of the grape berry so that the fruits can mature under relatively cool conditions (Palliotti et al., 2014). On the other hand, account should also be taken of those cultural techniques that may directly enhance the accumulation of polyphenols, among others leaf removal (LR).

Basal LR has been proven to be an effective practice to reduce disease incidence in grape bunches as well as to improve the fruit composition thanks to better illumination and air circulation in the cluster zone (Bledsoe et al., 1988; Smart \& Robinson, 1991; Poni et al., 2006; Tardáguila et al., 2010). Generally, it is more appropriate under cool and wet conditions where botrytis bunch rot is common and the grapes usually lack total soluble solids (TSS) and colour (Reynolds et al., 1986; Jackson \& Lombard, 1993; Lee \& Skinkis, 2013). On the other hand, under warm conditions the excessive exposure of the fruit may compromise the grape colour and acid (Haselgrove et al., 2000; Bergqvist et al., 2001) and even result in berry sunburn (Chorti et al., 2010).

The effects of LR depend largely on its timing. Before flowering, LR tends to lead to a lower yield by reducing the rate of fruit set (Poni et al., 2006; Tardáguila et al., 2010; Sivilotti et al., 2016). Since most berry abscission occurs within two to three weeks after full bloom (CandolfiVasconcelos \& Koblet, 1990), LR should be conducted at least two weeks after fruit set if an alteration in yield is unwanted. In contrast, late LR may suddenly expose the clusters to the strong midsummer sunlight, which could cause berry sunburn (Smart \& Robinson, 1991; Downey et al., 2006; He et al., 2010). It is worth mentioning that most previous LR experiments were conducted by only removing the basal leaves, with the lateral buds or shoots left behind. In this way the remaining leaves and the newly grown lateral shoots may have a higher assimilation rate, which could compensate for the reduction in leaf area (LA) caused by LR (Poni et al., 2006; Tardáguila et al., 2008; Diago et al., 2012). Moreover, cluster shading could reappear due to the lateral shoots, which means that the LR operation has to be repeated when necessary (Smart \& Robinson, 1991). Thus, in order to exert the influence of LR to a great extent, it is

*Corresponding author: Email address: zheng1987wei@gmail.com [Tel. ++34-625893463]

Acknowledgements: The authors extend their appreciation to the International Scientific Partnership Program ISPP at King Saud University for funding this research work through ISPP\# 0015 
necessary to ensure full exposure of the grapes by removing both basal leaves and lateral shoots surrounding the clusters, as long as the yield is not affected.

There are a great number of studies on the effects of LR on TA, pH and anthocyanins, etc. However, the results vary. In many studies, the mentioned parameters were determined at different levels of TSS for the LR treatment and the control group. In many cases, LR led to a higher sugar concentration than in the control when harvested at the same time, while the fruit that were exposed to sunlight usually had a higher anthocyanin concentration and TA and malic acid were reduced (Kliewer, 1977; Reynolds et al., 1986; Bledsoe et al., 1988; Smith et al., 1988; Poni et al., 2006; Diago et al., 2012). However, with global warming and the market tendency for low-alcohol wine (Palliotti et al., 2014), a high TSS level is increasingly undesirable. In addition, to evaluate the effects of a wine-growing technique on wine composition, it is more interesting to compare the parameters associated with acid and pigment at the same TSS content, since they are closely correlated with the TSS level. Otherwise it is difficult to evaluate the direct impact of the technique. Martínez de Toda \& Balda (2014) and Mosetti et al. (2016) report that, at a similar TSS level, LR after berry set reduced juice $\mathrm{pH}$ and malic acid, although this reduction in $\mathrm{pH}$ was not found in the studies of Lee and Skinkis (2013) and Sivilotti et al. (2016). Similarly, regarding TA, the results also differed in previous studies. Another key parameter of grape juice quality is the concentration of anthocyanins. Light exposure can exert some positive effects on anthocyanin accumulation in the cluster, while, in contrast, since grape colour enzyme activity ranges from $17^{\circ} \mathrm{C}$ to $26^{\circ} \mathrm{C}$ (Iland \& Gago, 2002), high temperatures tend to repress anthocyanin synthesis (He et al., 2010) and even delay the onset of anthocyanin accumulation (Sadras \& Moran, 2012). Coincidentally, both increased light exposure and high berry temperatures are the consequences of LR. To our knowledge, the total effects of LR on anthocyanins are still unclear, especially under warm conditions, although it has been stated that a high degree of bunch exposure might be harmful to anthocyanin accumulation (Haselgrove et al., 2000; Bergqvist et al., 2001; Guidoni et al., 2008; Chorti et al., 2010). Furthermore, few investigators have studied the impact of LR on the TSS content at the onset of anthocyanin synthesis; however, this value could influence the final anthocyanin concentration (Sadras \& Moran, 2012).

The aim of this research was to evaluate the effects of sustained bunch exposure through a severe basal LR on the quality of Tempranillo grapes under the environmental conditions of La Rioja, Spain and, more specifically, on its chemical composition and on the quality of the wine.

\section{MATERIALS AND METHODS}

\section{Plant material and growth conditions}

Over a period of three years (2014 to 2016), a field trial was carried out in an experimental vineyard $\left(42^{\circ} 27^{\prime} \mathrm{N}, 2^{\circ} 25^{\prime} \mathrm{W}\right.$, 370 m.a.s.1.) of the University of La Rioja, Logroño, Spain. Vitis vinifera L. cv. Tempranillo (clone CL-306 grafted onto 110-R rootstock) planted in 2010 was used for the experiment. Vine rows were oriented roughly north-south at a $2.4 \mathrm{~m}$ (between rows) $\times 1.2 \mathrm{~m}$ (between vines) spacing, and the vines were trained to vertical shoot positioning with two cordons and pruned to six spurs (12 buds) per vine. The cordons were supported by a single wire $70 \mathrm{~cm}$ above the ground, and the canopy was constrained and protected by three pairs of foliage wires at a height of 100, 150 and $200 \mathrm{~cm}$ respectively. In 2014 and 2016, the vineyard was drip-irrigated with an average amount of $4.5 \mathrm{~L} /$ vine/day from mid-July, when moderate to severe water stress was observed ( $70 \%$ of the shoots ceased growing), until the end of August. In 2015 , the irrigation was started two weeks earlier due to an enduring heat wave that started in the last week of June. Before veraison, trimming was performed once to prevent the shoots from extending to the street, which would make it difficult for us or tractors to get through.

\section{Treatments}

Four adjacent rows were selected for the study and, in each of them, two homogenous plots (five vines per plot) were assigned randomly to the control $(\mathrm{C})$ and LR treatments (one plot for $\mathrm{C}$ and the other for LR). The four rows served as four replicates, and both $\mathrm{C}$ and LR were performed on the same vines in all the experiment years. Every year the first six basal leaves (bunches are situated at three to five nodes) were removed manually from the LR vines two weeks after berry set, along with all the lateral shoots/buds in the basal zone.

\section{Measurement of TSS at the onset of anthocyanin synthesis} When $50 \%$ of the berries had begun to show colour in each of the treatments, 30 randomly selected berries with a slight sign of colour change were sampled for the TSS measurement using a digital refractometer (ATAGO Co., Ltd, Japan). In addition, based on three-year data, the correlativity between TSS at which anthocyanin synthesis was initiated and the effective accumulated temperature (the sum of the daily effective temperature. The daily effective temperature refers to the difference between the daily mean temperature and $10^{\circ} \mathrm{C}$, provided that the daily mean temperature is above $10^{\circ} \mathrm{C}$, otherwise it is $0^{\circ} \mathrm{C}$ ) from budburst to véraison was studied within each treatment group.

\section{Measurement of LA}

LA was estimated when the LR operation was conducted, as well as at harvest. The method based on leaf disc sampling (Smart \& Robinson, 1991) was used to estimate the leaf area per shoot. Fifteen shoots per treatment were taken at random for the measurement. For each of them, all the leaves (without leaf petioles) were removed and weighed. Meanwhile, 100 $3.80 \mathrm{~cm}^{2}$ discs from randomly selected leaves were weighed as well. LA per shoot was calculated by multiplying the quotient of the two weights by 380 . In the same way, the removed LA of the LR shoots was calculated, and then the percentage of LR on the whole canopy was estimated.

\section{Radiation and berry temperature measurements}

On 2016-08-07 (a representative summer day in the region, with burning sun and a cloudless sky), photosynthetically active radiation (PAR) at the cluster zone on both sides of the cordon was measured. The measurements were taken at three different times: four hours before solar noon (10:00), 
at solar noon (14:00) and four hours after solar noon (18:00). PAR was measured using a handheld Li-Cor LI189 quantum 1 m-length sensor (Li-Cor, Inc., Lincoln, NE), and ten measurements per replicate were carried out. The sensor was placed in a horizontal position on each side of the cluster zone along the cordon. Cluster sunlight exposure was expressed as the average percentage on both sides of the cordon related to the maximum PAR, which was measured perpendicularly to sun radiation. Independently, to evaluate the effects of radiation on berry temperature, 20 berries from the exposed (LR treatment), partly exposed ( $\mathrm{C}$ treatment but with gaps between leaves) and shaded ( $\mathrm{C}$ treatment, totally covered by leaves) clusters respectively were selected at midday for temperature measurements with an infrared "pistol type" thermometer (Optris LS, Mesurex SL, Berlin, Germany).

\section{Yield estimation, berry sampling and must analysis}

Intensive monitoring of the TSS content was conducted from late August, and the fruit were harvested as soon as their average TSS reached $22^{\circ}$ Brix, which is a common value for most of the red grapes in the region. For each treatment, the cluster number per vine was obtained by counting clusters on eight vines (two from each plot), and the cluster weight was measured on ten randomly cut clusters per repetition. Finally, yield per vine was estimated by multiplying both parameters (cluster number and cluster weight). Average berry weight was determined from 200 randomly sampled berries per repetition, and then these berries were crushed manually for the juice analysis. $\mathrm{pH}$, titratable acidity (TA), tartaric acid and malic acid were analysed by standard methods (OIV, 2014). The concentration of the total anthocyanins was measured based on Iland et al. (2004a).

\section{Winemaking, wine analysis and sensory evaluation}

Every year, the surplus grapes of both $\mathrm{C}$ and LR were harvested at $22^{\circ}$ Brix for micro-fermentations. Three $3 \mathrm{~L}$ jars of wine were elaborated per treatment, and each of them was filled with about three kilograms of grapes that had been de-stemmed manually. Grapes were crushed by hand inside the jar, and $3 \mathrm{ml}$ of $6 \%(6 \mathrm{~g} / 100 \mathrm{ml})$ sulphur dioxide $\left(\mathrm{SO}_{2}\right)$ solution was added to the juice. Afterwards, the juice was inoculated with $1.2 \mathrm{~g}$ of activated commercial yeast strain (Saccharomyces cerevisiae, OPTI-RED ${ }^{\circledR}$, Lallemand, Montreal, Canada). A round plastic cover with a hole in the middle was placed inside every jar to keep the berry skin in contact with the juice throughout the fermentation; in this way no manual punching down was performed. The fermentation was carried out at a constant temperature of $25^{\circ} \mathrm{C}$. About two weeks later, after the alcoholic fermentation was finished, the wine was pressed and $\mathrm{SO}_{2}$ was adjusted to $30 \mathrm{mg} / \mathrm{L}$. Wine was kept in a cold storage at $2{ }^{\circ} \mathrm{C}$ for two weeks before being racked. After bottling, wine bottles were placed horizontally and stored at about $18^{\circ} \mathrm{C}$ for two months before the chemical and sensory analysis. The TA and $\mathrm{pH}$ of the wine were measured according to standard methods (OIV, 2014). Colour intensity (CI) was estimated by adding together the absorption values at $420 \mathrm{~nm}, 520 \mathrm{~nm}$ and $620 \mathrm{~nm}$ (Glories, 1984). The total phenol index (TPI) was estimated by measuring the absorption at $280 \mathrm{~nm}$ (Ribéreau-Gayon,
1970). For both CI and TPI, the absorption was measured in a $1 \mathrm{~mm}$ optical path cell and then the results were multiplied by 10 , since the measure is conventionally referred to as the optical path of $10 \mathrm{~mm}$. The sensory evaluation was done for the wines of 2015 and 2016 using discrimination testing (paired comparison test) (Iland et al., 2004b). In order to identify if the wine from LR had particular attributes, some alternative questions with respect to acidity, astringency and off-flavour were posed. For each year, 10 experienced tasters participated and each of them repeated the paired comparison five times, so the number of paired tests conducted was 50 per year.

\section{Statistical analyses}

Statistical package SPSS 16.0 (SPSS Inc., Chicago, US) for Windows was used for the statistical analyses. An independent samples t-test was conducted for the comparison of the TSS at which the synthesis of the anthocyanins started between treatments. Pearson's correlation method with two-tailed test was applied for the correlation analysis. The data of yield components, berry composition and wine composition were tested for homogeneity of variance using Levene's test, and were subjected to two-way (treatment $\mathrm{x}$ year) analysis of variance using the general linear model and F-test. When there were significant differences among years, the S-N-K method (equal variances assumed) or Dunnett's T3 method (equal variances not assumed) was used to separate the means. Data were also analysed year by year using the independent samples t-test, since interaction between treatments and years was observed for some of the parameters. The results of the sensory analysis were interpreted based on the statistical table for the two-tailed test sourced from Amerine and Roessler (1976).

\section{RESULTS}

\section{Weather conditions}

The summer of 2014 was cool and the temperatures in September and October were much higher than the average (Fig. 1). Besides, there was a lot of precipitation throughout September $(56.0 \mathrm{~mm})$. The weather conditions of 2015 differed from those of 2014: the three months of summer were extremely hot, but the autumn was chilly. Moreover, it should be emphasised that there was a long-lasting heat wave for a period of two weeks at the end of June and the beginning of July. The 2016 season suffered from a lack of rain (data not shown) after a cold April, although the temperature in the summer was close to the annual average.

\section{TSS concentration at the onset of anthocyanin synthesis}

In each year, the LR grapes had a lower TSS concentration than the $\mathrm{C}$ grapes when the berries began to show colour, and this difference was significant in 2014 and 2016 (Fig. 2). It was also observed that the TSS level was strongly proportional to the effective accumulated temperature from budburst until véraison (Fig. 2); that is, the higher the temperature before véraison, the higher the TSS level when anthocyanin synthesis started, although this correlation failed to be significant statistically due to the data being only from three years. 


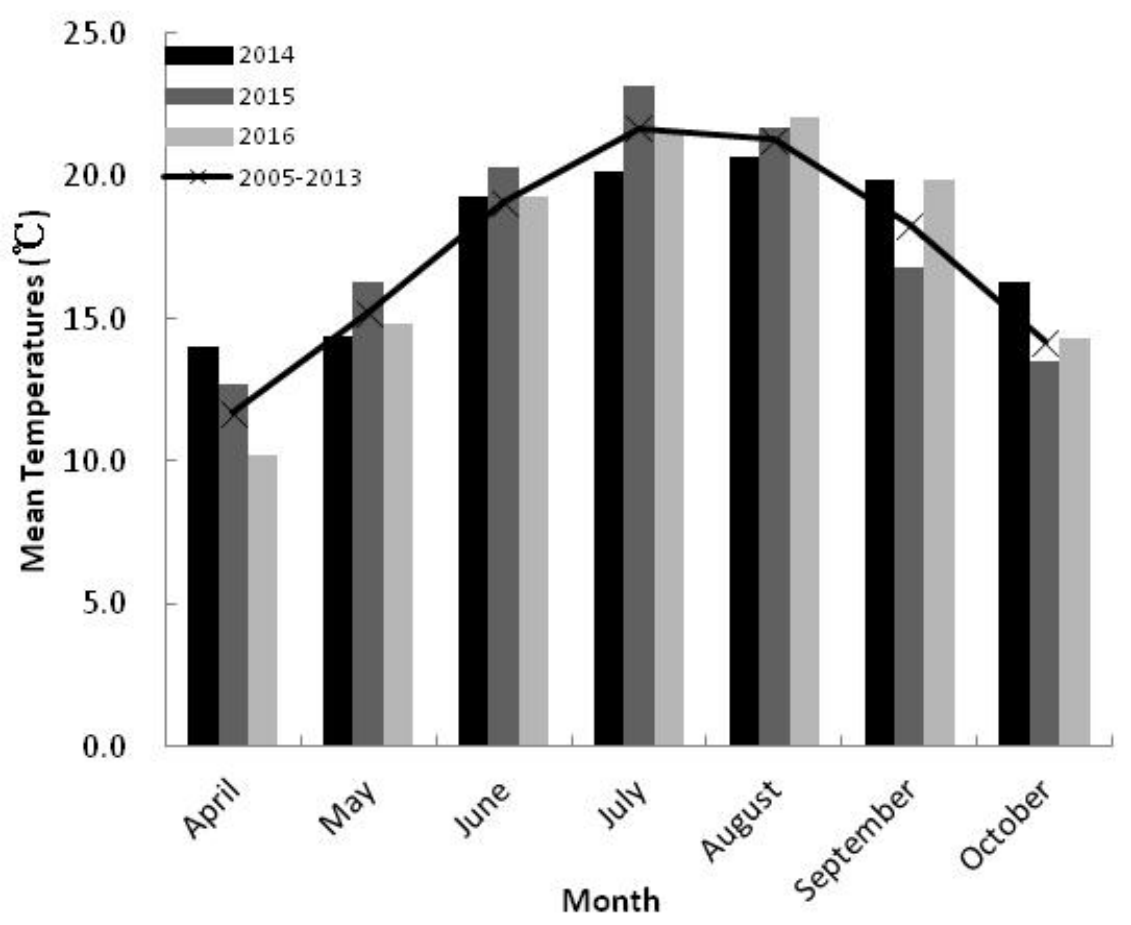

FIGURE 1

Mean monthly temperatures during growing seasons in Logroño.

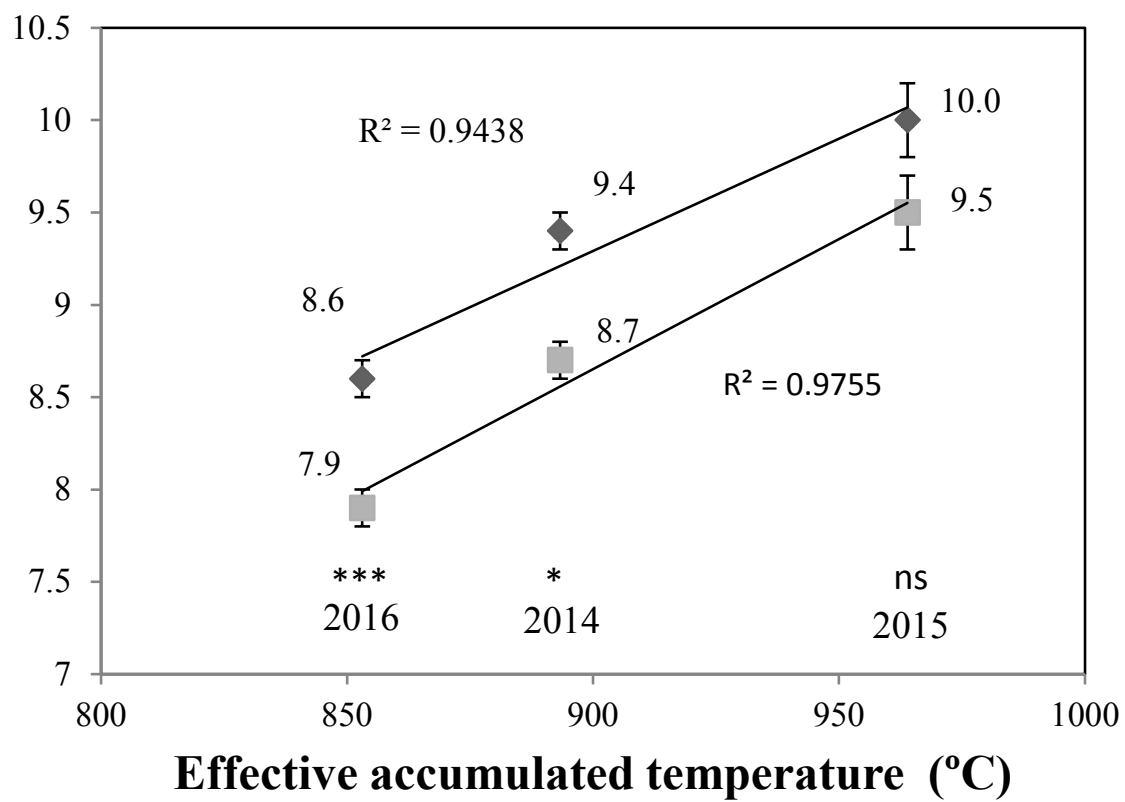

FIGURE 2

Linear correlation between the concentration of total soluble solids (TSS) at which anthocyanin synthesis was initiated and the effective accumulated temperature (the sum of the daily effective temperature. The daily effective temperature refers to the difference between the daily mean temperature and $10^{\circ} \mathrm{C}$, provided that the daily mean temperature is above $10^{\circ} \mathrm{C}$, otherwise it is $0^{\circ} \mathrm{C}$ ) from budburst to véraison, based on data from three years $(2014,2015$ and 2016). The Pearson correlation method with two-tailed test was applied, with significance at $p \leq 0.05$. Values are mean \pm SE. ( $\bullet)$ : Control; $(\varpi)$ : LR. TSS was also compared between treatments with an independent samples t-test; ${ }^{*}, * *$, ns: significant at $\mathrm{p} \leq 0.05, \mathrm{p} \leq 0.001$ or not significant , respectively. 


\section{Cluster sunlight exposure and berry temperature}

It is obvious that the LR grapes received much more illumination during the daytime than the $\mathrm{C}$ grapes (Fig. 3). As a result, the berry temperature of the LR grapes was supposed to be higher than those of the $\mathrm{C}$ grapes for most of the day. For example, our measurements showed that, at midday, the average surface temperatures of exposed (with an average illumination of $2000 \mu \mathrm{mol} / \mathrm{m}^{2} \mathrm{~s}$ ), partially exposed $\left(120 \mu \mathrm{mol} / \mathrm{m}^{2} \mathrm{~s}\right)$ and shaded $\left(4 \mu \mathrm{mol} / \mathrm{m}^{2} \mathrm{~s}\right)$ berries were $36.6^{\circ} \mathrm{C}, 30.3^{\circ} \mathrm{C}$ and $27.3^{\circ} \mathrm{C}$ respectively, and the air temperature at that time was $30.7^{\circ} \mathrm{C}$.

\section{Field parameters and yield components}

Only in 2014 did LR lead to a significantly lower berry weight compared to $\mathrm{C}$, and both cluster weight and production $(\mathrm{P})$ per vine were not altered by LR in any vintage (Table 1). Due to the fact that about $57 \%$ of canopy LA was removed by LR, LR had significantly less leaf area per vine compared to $\mathrm{C}$ at harvest. Nevertheless, the values of LA/P of both treatments were always greater than $1.0 \mathrm{~m}^{2} / \mathrm{kg}$. All of the abovementioned parameters varied with years and among the three years; 2015 could be characterised as a vigorous and productive season, with considerably bigger berries and clusters.

\section{Must composition}

At the same level of TSS, the grape juice of C and LR tended to have a similar concentration of titratable acidity as well as a similar pH (Table 2). However, with respect to tartaric acid and malic acid, significant differences were observed. LR juice usually contained a higher concentration of the former acid and a lower concentration of the latter one. Thus, compared to $\mathrm{C}$, a higher tartaric acid:malic acid ratio was obtained via LR. In 2014, LR resulted in a higher concentration of total anthocyanins, although this trend was not confirmed in the next two years. Likewise, no significant differences in anthocyanin content (expressed as $\mathrm{mg}$ /berry) were found between treatments. Comparing each year of the experiment, it is noteworthy that the highest anthocyanin concentration was reported in 2016, followed by 2014, and the grapes of 2015 had the poorest colour, although the difference between 2014 and 2015 was not significant.

\section{Chemical analysis and sensory evaluation of wine}

Wine made from LR grapes had significantly higher CI and TPI (Table 3). Partially in accordance with the results of the anthocyanin analysis for grape juice, the wine of 2015 showed the lowest colour intensity, while there was no significant difference between the wines of 2014 and 2016 in

TABLE 1

Impacts of basal leaf removal (LR) on field parameters and yield components for Tempranillo vines over a period of three years (2014 to 2016).

\begin{tabular}{|c|c|c|c|c|c|c|c|c|c|c|c|}
\hline & & $\begin{array}{l}\text { Budburst } \\
\text { date }\end{array}$ & $\begin{array}{l}50 \% \\
\text { véraison } \\
\text { date }\end{array}$ & $\begin{array}{l}\text { Harvest } \\
\text { date }\end{array}$ & $\begin{array}{l}\text { Berry } \\
\text { weight } \\
\text { (g) }\end{array}$ & $\begin{array}{l}\text { Cluster } \\
\text { weight } \\
\text { (g) }\end{array}$ & $\begin{array}{l}\text { Production } \\
(\mathrm{P}) \\
(\mathrm{kg} / \mathrm{vine})\end{array}$ & $\begin{array}{l}\text { Leaf area } \\
(\mathrm{LA}) \\
\left(\mathrm{m}^{2} / \text { vine }\right)\end{array}$ & $\begin{array}{l}\mathrm{LA} / \mathrm{P} \\
\left(\mathrm{m}^{2} / \mathrm{kg}\right)\end{array}$ & & \\
\hline \multirow[t]{3}{*}{2014} & Control & $6 \mathrm{Apr}$ & 4 Aug & $1 \mathrm{Oct}$ & $1.54 \mathrm{a}^{2}$ & 175 & 2.89 & $3.67 \mathrm{a}$ & 1.27 & 2014 & Control \\
\hline & LR & $6 \mathrm{Apr}$ & 5 Aug & $25 \mathrm{Sep}$ & $1.43 \mathrm{~b}$ & 135 & 2.46 & $2.81 \mathrm{~b}$ & 1.14 & & LR \\
\hline & $\operatorname{Sig}^{1}$ & & & & $* * *$ & ns & ns & $* * *$ & & & Sig $^{1}$ \\
\hline \multirow[t]{3}{*}{2015} & Control & 7 Apr & $28 \mathrm{Jul}$ & 11 Sep & 1.87 & 266 & 5.27 & $7.45 \mathrm{a}$ & 1.41 & 2015 & Control \\
\hline & LR & $7 \mathrm{Apr}$ & $30 \mathrm{Jul}$ & 11 Sep & 1.68 & 205 & 3.85 & $5.62 \mathrm{~b}$ & 1.46 & & LR \\
\hline & Sig & & & & ns & ns & ns & $*$ & & & Sig \\
\hline \multirow[t]{3}{*}{2016} & Control & 4 Apr & 3 Aug & 7 Sep & 1.37 & 220 & 3.84 & $5.34 \mathrm{a}$ & 1.39 & 2016 & Control \\
\hline & LR & 4 Apr & 3 Aug & $7 \mathrm{Sep}$ & 1.49 & 210 & 3.74 & $4.13 \mathrm{~b}$ & 1.10 & & LR \\
\hline & Sig & & & & ns & ns & ns & $* *$ & & & Sig \\
\hline Treatment & Control & $6 \mathrm{Apr}$ & $1 \mathrm{Aug}$ & $16 \mathrm{Sep}$ & 1.59 & 220 & $4.00 \mathrm{a}$ & $5.49 \mathrm{a}$ & 1.36 & Treatment & Control \\
\hline \multirow[t]{2}{*}{$(\mathrm{T})$} & LR & 6 Apr & $2 \mathrm{Aug}$ & 14 Sep & 1.56 & 183 & $3.35 \mathrm{~b}$ & $4.19 \mathrm{~b}$ & 1.23 & $(\mathrm{~T})$ & LR \\
\hline & Sig & & & & $\mathrm{ns}$ & ns & ns & $* * *$ & & & Sig \\
\hline Year & 2014 & $6 \mathrm{Apr}$ & 5 Aug & 28 Sep & $1.48 \mathrm{~b}$ & $155 \mathrm{~b}$ & $2.68 \mathrm{c}$ & $3.24 \mathrm{c}$ & 1.21 & Year & 2014 \\
\hline \multirow[t]{3}{*}{$(\mathrm{Y})$} & 2015 & 7 Apr & $29 \mathrm{Jul}$ & 11 Sep & $1.78 \mathrm{a}$ & $236 \mathrm{a}$ & $4.56 \mathrm{a}$ & $6.53 \mathrm{a}$ & 1.44 & $(\mathrm{Y})$ & 2015 \\
\hline & 2016 & 4 Apr & 3 Aug & $7 \mathrm{Sep}$ & $1.43 \mathrm{~b}$ & $215 \mathrm{a}$ & $3.79 \mathrm{~b}$ & $4.74 \mathrm{~b}$ & 1.25 & & 2016 \\
\hline & Sig & & & & $* * *$ & $*$ & $* * *$ & $* * *$ & & & Sig \\
\hline $\mathrm{T} \times \mathrm{Y}$ & Sig & & & & $*$ & ns & ns & ns & & $\mathrm{T} \times \mathrm{Y}$ & Sig \\
\hline
\end{tabular}

${ }^{1}$ Sig: Significance level; data within each year were analysed by independent samples t-test; data of three years were analysed with two-way Anova (treatments $\times$ years); ${ }^{*}, * * * *$, ns: significant at $\mathrm{p} \leq 0.05, \mathrm{p} \leq 0.01, \mathrm{p} \leq 0.001$ and not significant respectively.

${ }^{2} \mathrm{~S}-\mathrm{N}-\mathrm{K}$ method (equal variances assumed) or Dunnett's T3 method (equal variances not assumed) was used to separate the means when there were significant differences among years; different letters $(a, b, c)$ represent different means at $\mathrm{p} \leq 0.05$. 
TABLE 2

Impacts of basal leaf removal (LR) on Tempranillo grape juice over a period of three years (2014 to 2016).

\begin{tabular}{|c|c|c|c|c|c|c|c|c|}
\hline & & $\begin{array}{l}\text { TSS at } \\
\text { harvest } \\
\left({ }^{\circ} \text { Brix }\right)\end{array}$ & $\begin{array}{l}\text { Titratable } \\
\text { acidity } \\
(\mathrm{g} / \mathrm{L})^{2} \\
\end{array}$ & $\mathrm{pH}$ & $\begin{array}{l}\text { Tartaric } \\
\operatorname{acid}(\mathrm{g} / \mathrm{L})\end{array}$ & $\begin{array}{l}\text { Malic } \\
\text { acid } \\
(\mathrm{g} / \mathrm{L}) \\
\end{array}$ & $\begin{array}{l}\text { Anthocyanin } \\
\text { concentration } \\
(\mathrm{mg} / \mathrm{g}) \\
\end{array}$ & $\begin{array}{l}\text { Anthocyanin } \\
\text { content } \\
\text { (mg/berry) }\end{array}$ \\
\hline \multirow[t]{3}{*}{2014} & Control & 22.3 & 3.45 & 4.12 & 4.2 & $3.5 \mathrm{a}^{3}$ & $1.29 \mathrm{~b}$ & 1.97 \\
\hline & LR & 22.6 & 3.65 & 4.04 & 4.6 & $2.9 \mathrm{~b}$ & $1.45 \mathrm{a}$ & 2.31 \\
\hline & Sig $^{1}$ & $\mathrm{~ns}$ & ns & ns & ns & $*$ & $* * *$ & ns \\
\hline \multirow[t]{3}{*}{2015} & Control & 22.5 & 5.15 & 3.52 & $4.2 \mathrm{~b}$ & $4.2 \mathrm{a}$ & 1.21 & 2.03 \\
\hline & LR & 22.4 & 4.85 & 3.55 & $4.4 \mathrm{a}$ & $3.7 \mathrm{~b}$ & 1.35 & 2.26 \\
\hline & Sig & $\mathrm{ns}$ & ns & $\mathrm{ns}$ & $*$ & $* * *$ & ns & ns \\
\hline \multirow[t]{3}{*}{2016} & Control & 22.2 & 4.64 & 3.36 & $4.5 \mathrm{~b}$ & 4.3 & 1.65 & 2.23 \\
\hline & LR & 22.4 & 5.14 & 3.31 & $5.0 \mathrm{a}$ & 4.1 & 1.66 & 2.45 \\
\hline & Sig & $\mathrm{ns}$ & ns & ns & $* *$ & ns & ns & ns \\
\hline Treatment & Control & 22.3 & 4.41 & 3.67 & $4.3 \mathrm{~b}$ & $4.0 \mathrm{a}$ & 1.38 & 2.08 \\
\hline \multirow[t]{2}{*}{$(\mathrm{T})$} & LR & 22.5 & 4.55 & 3.63 & $4.7 \mathrm{a}$ & $3.6 \mathrm{~b}$ & 1.49 & 2.34 \\
\hline & Sig & ns & ns & $\mathrm{ns}$ & $* * *$ & $* * *$ & $\mathrm{~ns}$ & ns \\
\hline Year & 2014 & 22.5 & $3.55 \mathrm{~b}$ & $4.08 \mathrm{a}$ & $4.4 \mathrm{~b}$ & $3.2 \mathrm{a}$ & $1.37 \mathrm{~b}$ & 2.14 \\
\hline \multirow[t]{3}{*}{ (Y) } & 2015 & 22.5 & $5.00 \mathrm{a}$ & $3.53 \mathrm{~b}$ & $4.3 \mathrm{~b}$ & $3.9 \mathrm{~b}$ & $1.28 \mathrm{~b}$ & 2.15 \\
\hline & 2016 & 22.3 & $4.89 \mathrm{a}$ & $3.34 \mathrm{c}$ & $4.8 \mathrm{a}$ & $4.2 \mathrm{a}$ & $1.65 \mathrm{a}$ & 2.34 \\
\hline & Sig & $\mathrm{ns}$ & $* * *$ & $* * *$ & $* * *$ & $* * *$ & $* *$ & $\mathrm{~ns}$ \\
\hline $\mathrm{T} \times \mathrm{Y}$ & Sig & ns & $* *$ & ns & ns & ns & ns & ns \\
\hline
\end{tabular}

${ }^{1}$ Sig: Significance level; data within each year were analysed with the independent samples t-test; data of three years were analysed with twoway Anova (treatments $\times$ years); ${ }^{*},{ }^{*},{ }^{* * *}$, ns: significant at $\mathrm{p} \leq 0.05, \mathrm{p} \leq 0.01, \mathrm{p} \leq 0.001$ and not significant respectively.

2 The titratable acidity is expressed as $\mathrm{g} / \mathrm{L}$ tartaric acid.

${ }^{3} \mathrm{~S}-\mathrm{N}-\mathrm{K}$ method (equal variances assumed) or Dunnett's T3 method (equal variances not assumed) was used to separate the means when there were significant differences among years; different letters $(a, b, c)$ represent different means at $\mathrm{p} \leq 0.05$.

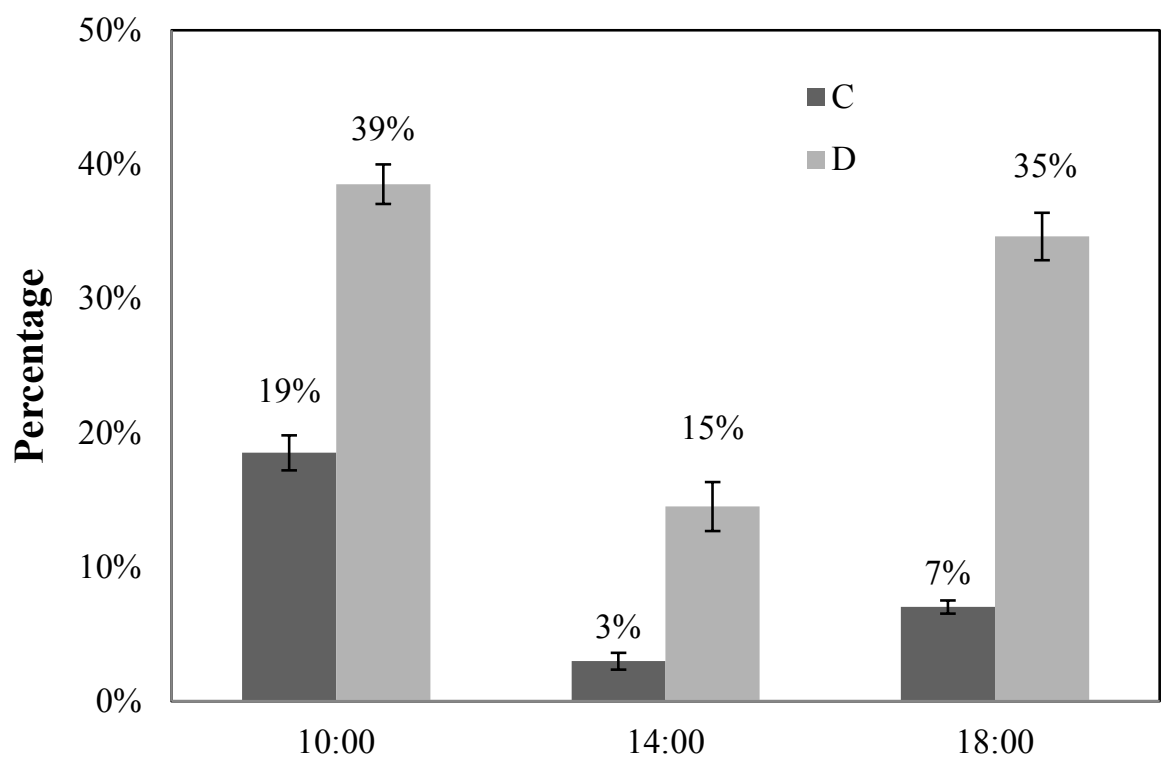

Time

FIGURE 3

The percentage (the average of both sides of the cordon) of the sunlight radiation received by both the control (C) and leaf removal (LR) clusters with respect to the real-time maximum radiation of a representative summer day (2016-08-07) in the Rioja wine region. Values are means $\pm \mathrm{SE}$. 
this aspect. Regarding the sensory analysis, the vast majority of the tasters in 2015 considered the LR wine to be more acid (Table 4). Perhaps because of this, the LR wine of 2015 was preferred considerably more by the tasters than the $\mathrm{C}$ wine of the same year. On the other hand, the sensory analysis of the wine of 2016 did not indicate any significant differences in all aspects.

\section{DISCUSSION}

Throughout the experiment we did not observe any symptoms of sunburn (brown patches or russet) on the berries, even under the extremely hot conditions that lasted up to two weeks in 2015. This could be explained by the fact that some plant secondary metabolites (i.e. phenolic compounds) could be produced in response to UV-B irradiation and these substances might contribute to the detoxification process and be able to protect the berries from further damage caused by intense solar radiation (Frohnmeyer \& Staiger, 2003; Keller, 2010; Webb et al., 2010). Generally, sudden exposure to sunlight under hot conditions is most likely to induce sunburn (Smart \& Robinson, 1991; Kuai et al., 2009). In our experiment, due to a basal leaf removal being carried out quite early, the fruit were supposed to have enough time to precondition and react so that sunburn was avoided. Moreover, since drip-irrigation was applied during most of the time from July to August, the vines might regulate their temperature by enhanced transpirational water loss, thus reducing the intensity of sunburn (Winkler, 1974; Van den Ende, 1999).

TABLE 3

Chemical analysis of the wine originating from the control (C) and leaf removal (LR) grapes of Tempranillo.

\begin{tabular}{llllll}
\hline & & Total acidity $(\mathrm{g} / \mathrm{L})^{2}$ & $\mathrm{pH}$ & Colour intensity $(\mathrm{CI})$ & Total phenols index $(\mathrm{TPI})$ \\
\hline Treatment $(\mathrm{T})$ & $\mathrm{C}$ & 4.3 & 4.25 & 9.60 & 39.2 \\
& $\mathrm{LR}$ & 4.7 & 4.19 & 12.86 & 45.5 \\
& $\mathrm{Sig}^{1}$ & $\mathrm{~ns}$ & $\mathrm{~ns}$ & $* * *$ & $*$ \\
Year $(\mathrm{Y})$ & 2014 & $4.3 \mathrm{~b}^{3}$ & 4.28 & $12.89 \mathrm{a}$ & 47.4 \\
& 2015 & $4.3 \mathrm{~b}$ & 4.24 & $8.62 \mathrm{~b}$ & 41.3 \\
& 2016 & $4.9 \mathrm{a}$ & 4.15 & $12.19 \mathrm{a}$ & 38.4 \\
& Sig & $*$ & $\mathrm{~ns}$ & $* *$ & $\mathrm{~ns}$ \\
$\mathrm{~T} \times \mathrm{Y}$ & $\mathrm{Sig}$ & $\mathrm{ns}$ & $\mathrm{ns}$ & $\mathrm{ns}$ & $\mathrm{ns}$ \\
\hline
\end{tabular}

${ }^{1}$ Sig: Significance level; data were analysed with two-way Anova (treatments $\times$ years); ${ }^{*},{ }^{* *}, * * *$, ns: significant at $\mathrm{p} \leq 0.05, \mathrm{p} \leq 0.01$, $\mathrm{p} \leq 0.001$ and not significant, respectively.

${ }^{2}$ Total acidity is expressed as $\mathrm{g} / \mathrm{L}$ tartaric acid.

${ }^{3} \mathrm{~S}-\mathrm{N}-\mathrm{K}$ method (equal variances assumed) or Dunnett's T3 method (equal variances not assumed) was used to separate the means when there were significant differences among years; different letters ( $a, b, c)$ represent different means at $\mathrm{p} \leq 0.05$.

TABLE 4

Sensory analysis of the wine originating from the control (C) and leaf removal (LR) grapes of Tempranillo with discrimination testing.

\begin{tabular}{|c|c|c|c|c|c|}
\hline \multicolumn{6}{|c|}{ Question: Which wine is more prominent concerning the following characters? } \\
\hline & Unpleasant aroma & Off-flavour & Sensation of acidity & Astringency & Overall preference \\
\hline \multicolumn{6}{|c|}{2015} \\
\hline $\mathrm{C}$ & $28^{1}$ & 28 & 14 & 29 & 14 \\
\hline LR & 22 & 22 & 36 & 21 & 36 \\
\hline $\operatorname{Sig}^{2}$ & ns & ns & $* *$ & ns & $* *$ \\
\hline \multicolumn{6}{|c|}{2016} \\
\hline $\mathrm{C}$ & 27 & 30 & 23 & 31 & 18 \\
\hline LR & 23 & 20 & 27 & 19 & 32 \\
\hline Sig & ns & ns & ns & ns & ns \\
\hline
\end{tabular}

${ }^{1}$ The value represents the number of times the corresponding answer was recorded.

${ }^{2}$ Sig: Significance level; the two-tailed test statistical table sourced from Amerine and Roessler (1976) was used to determine if the number was sufficiently high to draw a statistically significant conclusion; since 50 paired tests were conducted, the number of corresponding answers needs to be 33 or higher to be significant at the $5 \%$ level and 35 or higher to be significant at the $1 \%$ level; **, ns: significant at $\mathrm{p} \leq 0.01$ and not significant, respectively. 
The results on the TSS concentration at the onset of anthocyanin synthesis are notable. We attribute the earlier onset of anthocyanin synthesis for LR to the positive effect of cluster exposure on the synthesis of anthocyanins. It seems that the positive effect of the increased exposure of berries to light predominates the possible negative effects of higher temperature. It is well known that, after véraison, the accumulation of anthocyanins depends mainly on the TSS level, as glucose is the precursor of all the anthocyanins in the grapes (Pirie \& Mullins, 1977). Thus, the lower level of TSS (due to LR) at which the anthocyanin synthesis is initiated might be an indicator of a higher final concentration of anthocyanins at a given final TSS level, despite the fact that anthocyanins are also related to sunlight exposure and berry temperature during the period of ripening ( $\mathrm{He}$ et al., 2010). Sadras and Moran (2012) reported that elevated temperatures could delay the onset of anthocyanin synthesis in Shiraz and Cabernet Franc grapes. Similarly, the same trend was found in our study when comparing the results of the three years (independent of treatments). Overall, for a given variety, both cultural practices and pre-véraison weather conditions might alter the required TSS for the onset of anthocyanin synthesis. For instance, in addition to early LR, water deficit is also likely to accelerate the pigmentation process of grapes (Herrera \& Castellarin, 2016).

The reason for the smaller berry size of the LR grapes in 2014 might be that, after the basal leaves were removed, the division of mesocarp and skin cells was negatively affected because of the reduction in photosynthesis, as these cells would not cease dividing until three to five weeks after anthesis (Keller, 2010). However, in 2015 and 2016, the difference in berry size was not observed between treatments. Mosetti et al. (2016) reported that basal LR 25 days after anthesis did not affect berry size. In the study by Sivilotti et al. (2016), basal LR failed to change the berry mass, even when performed 15 days after flowering. Nonetheless, in our view, to avoid the risk of yield loss, LR ought not to be conducted within two weeks after fruit set. The values of $\mathrm{LA} / \mathrm{P}$ at harvest indicate that this parameter is neither a limiting factor for grape quality in both treatments nor a key factor causing differences in juice composition between the treatments.

Being exposed to direct solar radiation, LR berries might have a considerably higher surface temperature than those of $\mathrm{C}$ in the daytime. Accordingly, the differences in light conditions and berry temperatures between treatments might give rise to the different juice compositions. From the perspective of acid, high light intensity and berry temperature might affect metabolic processes that convert sugar to acids, which could provide an explanation for why the LR berries contained more tartaric acid (Keller, 2010). On the other hand, high berry temperatures were likely to accelerate the respiratory malate degradation, which resulted in lower malic acid (Keller, 2010). Compared to malic acid, tartaric acid has higher metabolic stability as well as higher microbiological stability. Besides, it could provide wine with a crisp and fresh mouthfeel, while malic acid tastes tart. Overall, a higher tartaric acid:malic acid ratio is usually what a winemaker wants and, fortunately, it seems possible to achieve this objective by applying LR shortly after fruit set. With regard to TA, the absence of significant differences between treatments is not surprising, as both tartaric and malic acid are not accurate indicators of TA (Boulton, 1980b). These findings agree with what Martínez de Toda and Balda (2014) found for Maturana grapes in the same region. However, in their study, a significantly reduced $\mathrm{pH}$ was achieved by increasing grape sunlight exposure, whereas we did not find this trend in our experiment, with the possible reason being that $\mathrm{pH}$ is usually influenced by the concentration of potassium and sodium ion in the juice (Boulton, 1980a).

In 2014, the significantly higher concentration of anthocyanins in the LR grapes might have been caused by their smaller berry size, since no considerable difference in anthocyanin content was found between treatments in the same year. Throughout the three-year data, LR did not exert positive (or negative) effects on the final pigment content of the grapes, in spite of the reduced level of TSS at the onset of anthocyanin synthesis. Therefore, under our experimental conditions, the repressed anthocyanin synthesis due to high berry temperature could have been cancelled out by the better fruit light conditions (He et al., 2010). On the other hand, the higher CI and TPI indicate that, relative to C, LR wine had darker colour and stronger body, which might be ascribed to sunlight exposure improving the extractability of anthocyanins during fermentation and enhancing the accumulation of skin tannin (Cortell \& Kennedy, 2006).

Since the LR grapes were exposed to the sunlight for a long period, one of our concerns about the LR wine was that it might develop some unpleasant aromas or off-flavours related to the high temperatures, similar to those of raisins. However, such defects were not detected in the sensory evaluation. Moreover, in spite of the higher TPI, the LR wines were not considered more astringent by the tasters. In brief, as a conservative conclusion, the clusters that received full exposure had no negative effects on wine quality under the conditions of our experiment.

\section{CONCLUSIONS}

Under the environmental conditions of La Rioja, a severe basal LR (with lateral shoots/buds also being removed) two weeks after fruit set is not likely to alter the yield components of Tempranillo grapes. The full exposure of the clusters did not bring about problems of sunburn; rather, several positive effects were obtained, such as a reduced TSS level at the onset of anthocyanin synthesis, as well as a better acid composition. Additionally, LR turned out to be an effective way to improve the colour and body of the wine. Viticulturists in the Rioja wine region might apply this winegrowing technique to improve grape berry and wine quality.

\section{LITERATURE CITED}

Amerine, M.A. \& Roessler, E.B., 1976. Wines. Their sensory evaluation. Freeman, San Francisco.

Bergqvist, J., Dokoozlian, N. \& Ebisuda, N., 2001. Sunlight exposure and temperature effects on berry growth and composition of Cabernet Sauvignon and Grenache in the Central San Joaquin Valley of California. Am. J. Enol. Vitic. 52, 1-7. 
Bledsoe, A., Kliewer, W. \& Marois, J., 1988. Effects of timing and severity of leaf removal on yield and fruit composition of Sauvignon blanc grapevines. Am. J. Enol. Vitic. 39, 49-54.

Boulton, R., 1980a. The general relationship between potassium, sodium and $\mathrm{pH}$ in grape juice and wine. Am. J. Enol. Vitic. 31, 182-186.

Boulton, R., 1980b. The relationships between total acidity, titratable acidity and $\mathrm{pH}$ in wine. Am. J. Enol. Vitic. 31, 76-80.

Candolfi-Vasconcelos, M. \& Koblet, W., 1990. Yield, fruit quality, bud fertility and starch reserves of the wood as a function of leaf removal in Vitis vinifera-Evidence of compensation and stress recovering. Vitis 29, 199-221.

Chorti, E., Guidoni, S., Ferrandino, A. \& Novello, V., 2010. Effect of different cluster sunlight exposure levels on ripening and anthocyanin accumulation in Nebbiolo grapes. Am. J. Enol. Vitic. 61, 23-30.

Cortell, J.M. \& Kennedy, J.A., 2006. Effect of shading on accumulation of flavonoid compounds in (Vitis vinifera L.) pinot noir fruit and extraction in a model system. J. Agr. Food. Chem. 54, 8510-8520.

Diago, M.P., Ayestarán, B., Guadalupe, Z., Poni, S. \& Tardáguila, J., 2012. Impact of prebloom and fruit-set basal leaf removal on the flavonol and anthocyanin composition of Tempranillo grapes. Am. J. Enol. Vitic. 63, 367-376.

Downey, M.O., Dokoozlian, N.K. \& Krstic, M.P., 2006. Cultural practice and environmental impacts on the flavonoid composition of grapes and wine: A review of recent research. Am. J. Enol. Vitic. 57, 257-268.

Frohnmeyer, H. \& Staiger, D., 2003. Ultraviolet-B radiation-mediated responses in plants. Balancing damage and protection. Plant Physiol. 133, 1420-1428.

Glories, Y., 1984. La couleur des vins rouges. 2e partie: Mesure, origine et intèrprétation. OENO One 18, 253-271.

Guidoni, S., Ferrandino, A. \& Novello, V., 2008. Effects of seasonal and agronomical practices on skin anthocyanin profile of Nebbiolo grapes. Am. J. Enol. Vitic. 59, 22-29.

Haselgrove, L., Botting, D., Heeswijck, R.V., Høj, P., Dry, P., Ford, C. \& Land, P., 2000. Canopy microclimate and berry composition: The effect of bunch exposure on the phenolic composition of Vitis vinifera L cv. Shiraz grape berries. Aust. J. Grape Wine Res. 6, 141-149.

He, F., Mu, L., Yan, G., Liang, N., Pan, Q., Wang, J., Reeves, M.J. \& Duan, C., 2010. Biosynthesis of anthocyanins and their regulation in colored grapes. Molecules 15, 9057-9091.

Herrera, J.C. \& Castellarin, S.D., 2016. Preveraison water deficit accelerates berry color change in Merlot grapevines. Am. J. Enol. Vitic. 67, 356-360.

Iland, P. \& Gago, P., 2002. Australian wines. Styles and tastes. Patrick Iland Wine Promotions, Campbelltown, SA, Australia.

Iland, P., Bruer, N., Edwards, G., Weeks, S. \& Wilkes, E., 2004a. Chemical analysis of grapes and wine: Techniques and concepts. Patrick Iland Wine Promotions, Campbelltown, SA, Australia.

Iland, P., Bruer, N., Ewart, A., Markides, A. \& Sitters, J., 2004b. Monitoring the winemaking process from grapes to wine techniques and concepts. Patrick Iland Wine Promotions, Adelaide, SA, Australia.

Jackson, D. \& Lombard, P., 1993. Environmental and management practices affecting grape composition and wine quality - A review. Am. J. Enol. Vitic. 44, 409-430

Keller, M., 2010. The science of grapevines: Anatomy and physiology. Academic Press, London.

Kliewer, W.M., 1977. Influence of temperature, solar radiation and nitrogen on coloration and composition of Emperor grapes. Am. J. Enol. Vitic. 28, 96-103.
Kuai, C., Liu, S., Wu, G., Yang, C., Chen, Y., Wang, P., Liu, C. \& Yu, Q., 2009. Analysis of the main factors and threshold temperature on Vitis berry sunburn [J]. Acta Horticulturae Sinica 36(8), 1093-1098.

Lee, J. \& Skinkis, P.A., 2013. Oregon 'Pinot noir'grape anthocyanin enhancement by early leaf removal. Food Chem. 139, 893-901.

Martínez de Toda, F. \& Balda, P., 2014. Reducing the pH of wine by increasing grape sunlight exposure: A method to mitigate the effects of climate warming. Vitis 53(1), 17-20.

Mosetti, D., Herrera, J., Sabbatini, P., Green, A., Alberti, G., Peterlunger, E., Lisjak, K. \& Castellarin, S., 2016. Impact of leaf removal after berry set on fruit composition and bunch rot in Sauvignon blanc. Vitis 55, 57-64.

OIV, 2014. Compendium of international methods of analysis of wines and musts. Bull OIV, Paris

Palliotti, A., Tombesi, S., Silvestroni, O., Lanari, V., Gatti, M. \& Poni, S., 2014. Changes in vineyard establishment and canopy management urged by earlier climate-related grape ripening: A review. Scientia Hortic. 178, 43-54.

Pirie, A. \& Mullins, M., 1977. Interrelationships of sugars, anthocyanins, total phenols and dry weight in the skin of grape berries during ripening. Am. J. Enol. Vitic. 28, 204-209.

Poni, S., Casalini, L., Bernizzoni, F., Civardi, S. \& Intrieri, C., 2006. Effects of early defoliation on shoot photosynthesis, yield components, and grape composition. Am. J. Enol. Vitic. 57, 397-407.

Reynolds, A., Pool, R. \& Mattick, L., 1986. Influence of cluster exposure on fruit composition and wine quality of Seyval blanc grapes. Vitis 25, 85-95.

Ribéreau-Gayon, P., 1970. Le dosage des composés phénoliques totaux dans les vins rouges. Chim. Anal. 52(6), 627-631.

Sadras, V.O. \& Moran, M.A., 2012. Elevated temperature decouples anthocyanins and sugars in berries of Shiraz and Cabernet Franc. Aust. J. Grape Wine Res. 18, 115-122.

Sivilotti, P., Herrera, J.C., Lisjak, K., Baša Česnik, H., Sabbatini, P., Peterlunger, E. \& Castellarin, S.D., 2016. Impact of leaf removal, applied before and after flowering, on anthocyanin, tannin, and methoxypyrazine concentrations in 'Merlot' (Vitis vinifera L.) grapes and wines. J. Agr. Food Chem. 64(22), 4487-4496.

Smart, R. \& Robinson, M., 1991. Sunlight into wine: A handbook for winegrape canopy management. Winetitles, Australia.

Smith, S., Codrington, I.C., Robertson, M. \& Smart, R.E., 1988. Viticultura and oenological implications of leaf removal for New Zealand vineyards. Proc. 2nd International Symposium for Cool Climate Viticulture and Oenology, June 1986, Auckland, New Zealand. pp. 127 - 133.

Tardáguila, J., Diago, M.P., Martinez de Toda, F., Poni, S. \& Vilanova de la Torre, M.d.M., 2008. Effects of timing of leaf removal on yield, berry maturity, wine composition and sensory properties of cv. Grenache grown under non irrigated conditions. J. Int. Sci. Vigne Vin 42(4), 221-229.

Tardáguila, J., Martinez de Toda, F., Poni, S. \& Diago, M.P., 2010. Impact of early leaf removal on yield and fruit and wine composition of Vitis vinifera L. Graciano and Carignan. Am. J. Enol. Vitic. 61, 372-381.

Van den Ende, B., 1999. Sunburn management. Compact Fruit Tree 32(1), 13-14.

Webb, L., Whiting, J., Watt, A., Hill, T., Wigg, F., Dunn, G., Needs, S. \& Barlow, E., 2010. Managing grapevines through severe heat: A survey of growers after the 2009 summer heatwave in south-eastern Australia. J. Wine Res. 21, 147-165.

Winkler, A.J., 1974. General viticulture. University of California Press, Berkeley, Canada 